\title{
Studies on Phytocoenosis Configuration in Rain Garden Landscape Design in Nanchang
}

\author{
Shuzhen Zou ${ }^{1, a_{*}}$, Wanjun Duan², Yirong Zhu ${ }^{3}$, Biaohong Tao ${ }^{1}$ \\ ${ }^{1}$ Jiangxi Science and Technology Normal University, Nanchang, Jiangxi Province 330006 \\ ${ }^{2}$ Jiangxi Ceramic and Art Institute, Jingdezhen,Jiangxi Province 333000 \\ ${ }^{3}$ Leshan Normal University, Leshan, Sichuan Province 614000 \\ azsz2928@163.com
}

Keywords: Nanchang, rain garden, phytocoenosis, configuration, landscape design.

\begin{abstract}
Against the increasing cementation in cities, the rain garden, as an urban green infrastructure, has been increasingly focused on in terms of alleviating urban waterlogging, rainwater runoff pollution, groundwater level decline and conserving biodiversity. In its design, it is vital to select and design plants and their communities, directly affecting landscape functions and post effects. Based on the analysis of current rain garden plants at home and abroad, in combination with natural conditions of Nanchang, this paper discusses the selection principles for local plants and their communities, proposing 5 phytocoenosis combinations suitable for rain gardens in Nanchang.
\end{abstract}

\section{Domestic and international rain garden plant research}

The rain garden is an ecologically sustainable rainwater control and utilization facility, also known as a biological retention area. It is a naturally occurring or artificially excavated low-lying green space used to converge and absorb rainwater from roofs or grounds, applying combined actions of barks, plants and sand to intercept, drain and purify rainwater. Its concept was first proposed by some rainwater experts from Maryland, the United States, in 1990, and was built and used in Prince George County, Maryland. With its efficient and economical approach, it has been extensively promoted in some developed countries such as the United States, Canada and Australia. ${ }^{[1]}$ Plants are its most important composition. Relevant international researchers have conducted sufficient in-depth studies, focusing on the different sewage and pollutants removing ability of different plants, ability of plant roots to restore soil permeation and impact of different environmental factors on rain garden plants. In terms of international rain garden projects, it has been mature in the comprehensive application of its plants, such as selection of plant species for different types, its overall function, its maintenance and management.

At present, China is still in the exploratory research stage for rain garden development, centering on its development technology, scale and structure, insufficient in its plant basic research. Rich in rainwater resources, Nanchang takes rainwater effective utilization as one of the important steps towards an eco-city, and rain garden phytocoenosis as a driving force, of great significance to Nanchang rain garden development, making rain garden development as a catalyst for city landscape ecological benefits, social benefits and landscape benefits.

\section{Nanchang rain garden plant selection principles and configuration methods}

\subsection{Rain Garden Plant Selection Principle}

Selection of rain garden plant species should consider the ornamental value and its environment.

\footnotetext{
* Shuzhen Zou , Professor of Jiangxi Science \& Technology Normal University, main research direction: environmental art; Wanjun Duan,Teacher of Jiangxi Ceramic and Art Institute , main research direction: environmental art; Yirong Zhu, Teacher of Leshan Normal University, main research direction: environmental art; Biaohong Tao, Professor of Jiangxi Science \& Technology Normal University, main research direction: applied economics.
} 


\subsubsection{Centering on native plants, and appropriately introducing exotic plants}

Through long-term cultivation, the native plants have adapted to the local climate and natural ecological environment, with high anti-pollution, resistance to pests and diseases, and safe, cheap and low conservation characteristics. Local plants often represent the plant characteristics of the local region. Reflecting geographical characteristics of the region, some native plants highlight unique cultural characteristics, and profound historical and cultural heritages. Rain garden plants should focus on native plants. Enrich local landscape characteristics, it is proper to introduce some exotic plants, without violating the natural laws. It is necessary to consider the introduction in terms of local climate, soil, water and other environmental factors, preventing exotic plant invasion ${ }^{[2]}$.

\subsubsection{Centering on the local environment, appropriately selecting suitable plants}

Rain gardens aim to stop retention, penetrate and purify rainwater. In rainy season, a large amount of storm water is stopped in the ground while in dry season rain water is insufficient. Therefore, rain garden plants should give priority to both water resistance, and drought-resistance. To strengthen rain garden infiltration and purification capacities, it is necessary to select plants with developed root systems, lush foliage and high stress resistance. It is necessary to select plants with strong adsorption of pollutants in rainwater, and consider rational mixing and enhance comprehensive decontamination capacities. ${ }^{[3]}$

\subsubsection{Centering on fast-growing plants, in combination with slow-growing plants}

Urban rain garden fast-growing plants are conducive to the formation of landscape effects in the short term, and combination with slow-growing plants achieves the landscape sustainability.

\subsection{Rain garden phytocoenosis development methods}

2.2.1 It is proper to select rain garden plant species especially dominant species according to the garden functional requirements.

Rain gardens of different types and properties need different plant combinations. Those aiming at controlling runoff pollution and runoff amount should focus on pollution absorption and resistance, and resistant to certain water-dampness, such as Pterocarya stenoptera C. DC., Sapium sebiferum (L.) Roxb., Yucca gloriosa L., Hibiscus syriacus Linn., Miscanthus sinensis cv., Dichondra repens Forst., Phragmites australias Trin, and Acorus calamus L.. In addition, appropriate increase in phytocoenosis density can effectively stop rainwater.

\subsubsection{Phytocoenosis layout based on site nature;}

Rain garden phytocoenosis witnesses natural and regular layout, and combination of the two. Rain garden phytocoenosis such as urban streets, parking lots, squares and public buildings favor the regular layout, further emphasizing landscape unity while those in rainwater parks, residential areas and factories favor the natural layout, further emphasizing landscape changes and rustic charm. In short, the phytocoenosis combine natural and regular layout to create colorful plant landscapes.

\subsubsection{Simulating natural phytocoenosis composition structure, restoring zonal vegetation;}

It is proper to establish phytocoenosis vertical stratification and horizontal distribution according to plant environmental factors such as light, temperature, water and soil. Natural phytocoenosis vertical and horizontal distribution is generally uneven because of different climatic environmental factors, especially the phytocoenosis crisscross with high productivity, abundant species and high phytocoenosis density, such as wetland and forest edges. The rain garden phytocoenosis should simulate the marginal effect of natural communities so as to improve the overall ecological benefits, distributing mesophyte phytocoenosis, humidogene phytocoenosis, emergent phytocoenosis, floating phytocoenosis, and submerged phytocoenosis according to the zonal distribution from land to water. Rain garden zonal phytocoenosis needs to take into account the garden scale, site conditions and design objectives. 
2.2.4 Appropriately applying vertical mixing and horizontal mixing technology to establish stable phytocoenosis.

[4] Rain garden phytocoenosis should have complex structures to form multiple levels such as trees, bushes, grass and ground covers. In fact, the more abundant the plant species are, the more complex the phytocoenosis structure will be, and the higher the productivity will become, maintaining phytocoenosis long-term stability.

\subsubsection{Establishing ornamental phytocoenosis based on plant seasonal variations;}

Seasonal changes make phytocoenosis appearance change periodically. The phytocoenosis colors are originated from barks, leaves, flowers and fruits. In practice, seasonal variations of evergreen plants are not significant, and seasonal variations of herbaceous plants are most obvious, and deciduous broad-leaved phytocoenosis is quite obvious, such as Sapium sebiferum (L.) Roxb., Acer palmatum Thunb, Acer buergerianum Miq, Liquidambar formosana Hance, Elaeocarpus decipiens Hemsl and Pterocarya stenoptera C. DC., which will turn to red in autumn and winter or early spring; Ginkgo biloba L, Salix babylonica, Metasequoia glyptostroboides Hu \& W. C. Cheng, Lagerstroemia indica L., Ulmus parvifolia Jacq and h Celtis sinensis Pers, which will turn golden yellow or brown.

\section{Rain garden phytocoenosis suitable for planting in Nanchang}

\subsection{Natural climatic conditions in Nanchang}

Nanchang has a typical subtropical monsoon climate, warm and humid, with 4 distinct seasons, large temperature difference, rainy spring, hot summer, dry autumn and cold winter. The annual average temperature is $17.4^{\circ} \mathrm{C}$. Nanchang is one of the areas in China with the highest temperature in summer. July and August witness the highest temperature, $29.3^{\circ} \mathrm{C}$ on the average, maximum $40^{\circ} \mathrm{C}$. From December to February, the average temperature is $5.2^{\circ} \mathrm{C}$, and the coldest month is January with the lowest temperature of $-7.7^{\circ} \mathrm{C}$. Nanchang has sufficient rainfall, an annual average precipitation of $1760.3 \mathrm{~mm}$, annual 128.3 rainy days on the average; April to June witness the rainy reason, with an average monthly rainfall of more than $280 \mathrm{~mm}$; September to November witness the dry season with an average daily rainfall of less than $100 \mathrm{~mm}$, with an annual relative humidity of $81 \%$, with minor changes in months, an average frost-free period of 277 days; winter witnesses cold waves, and the local terrain often causes wind scale 6-7 and frost, late summer and early autumn occasionally witness typhoon invasion. Nanchang has its typical vegetation as subtropical evergreen broad-leaved forests.

\subsection{Recommended rain garden phytocoenosis suitable for planting in Nanchang}

Phytocoenosis must be configured according to the design scale and site conditions of the rain garden. According to its flooding, the rain garden can be divided into water storage area, buffer area and marginal area. ${ }^{[5]}$ Most of the local plants in the marginal area can be configured, without requiring plant water resistance. The buffer area directly affected by the rainy season is suitable for waterlogging resistance, well-developed perennials, with humidogene and emergent phytocoenosis as the best choice. The water storage area should be configured with emergent, floating-leaved and submerged phytocoenosis based on the water level, emergent plants especially floating-leaved phytocoenosis should select phytocoenosis and dominant phytocoenosis and control the planting range. Multiple phytocoenosis morphology is conducive to rich regional and zonal natural landscape characteristics. Water-resistant shrub grass structure, tree-grass structure, shrub structure and other components can form ever-changing phytocoenosis. 
The following are 5 recommended phytocoenosis combinations suitable for rain gardens in Nanchang:

(1) Taxodium ascendens Brongn. + Metasequoia glyptostroboides Hu \& W. C. Cheng + Salix rosthornii Seemen + Salix matsudana Koidz + Salix babylonica - Salix integra 'Hakuro Nishiki' + Hibiscus syriacus Linn. + Lonicera japonica Thunb. - Paspalum thunbergii Kunth ex Steud + Imperata cylindrica (L.) Beauv. - Lythrum salicaria L. + Iris pseudacorus L. + zizania aquatica, Metasequoia glyptostroboides Hu \& W. C. Cheng + Taxodium ascendens Brongn. + Taxodium distichum (L.) Rich. + Salix rosthornii Seemen + Clerodendrum inerme (L.) Gaerth - Iris tectorum Maxim. + Glechoma longituba (Nakai) Kupr - Scirpus validus Vahl + Arundo donax var. versicolor + Oenanthe javanica (Blume) DC, Taxodium distichum (L.) Rich. + Metasequoia glyptostroboides Hu \& W. C. Cheng + T Taxodium mucronatum Tenore + Castanopsis sclerophylla

(Lindl.) Schott. + Elaeocarpus decipiens Hemsl. - Ternstroemia gymnanthera (Wight et Arn.) Beddome + Buddleja davidii Franch. + Jasminum nudiflorum Lindl. - Cynodon dactylon (L.) Pers. + Cynodon dactylon (L.) Pers. + Paspalum thunbergii Kunth ex Steud. - Phragmites australias Trin. + Monochoria korsakowii Regel \& Maack + Typha orientalis Presl + Acorus calamus L.

(2) Cinnamomum camphora (L.) Presl. + Sapium sebiferum (L.) Roxb. + Salix babylonica + Salix matsudana Koidz - Hibiscus mutabilis Linn. + Lagerstroemia indica L. + Forsythia suspensa -Carex 'Evergold'+ Weigela florida 'Variegata', Cinnamomum camphora (L.) Presl. + Acer palmatum Thunb + Elaeocarpus decipiens Hemsl. + Malus hupehensis (Pamp.) Rehd. + Eriobotrya japonica (Thunb.) Lindl. - Osmanthus sp. + Lagerstroemia indica L. + Salix integra 'Hakuro Nishiki' -Medicago sativa L. + Ophiopogon japonicus (Linn. f.) Ker-Gawl. + Orychophragmus violaceus + Miscanthus sinensis cv. + Cynodon dactylon (L.) Pers. -Acorus calamus L. + Typha orientalis Presl + Lythrum salicaria L. + Zelkova serrata + Ulmus pumila L. + Castanopsis sclerophylla (Lindl.) Schott. -Gardenia jasminoides var. radicans Makino + Yucca gloriosa L. + Camellia japonica L. -Dichondra repens Forst. + Ophiopogon japonicus (Linn. f.) Ker-Gawl. + Cynodon dactylon (L.) Pers. + Scirpus validus Vahl-Scirpus validus Vahl + Iris pseudacorus L. + Pontederia cordata L. + Monochoria korsakowii Regel \& Maack + Pistia stratiotes + Eichhornia crassipes (Mart.) Solms + Vallisneria natans (Lour.) Hara + Ceratophyllum demersum $L$.

(3)Pterocarya stenoptera C. DC. + Acer buergerianum Miq. + Sapium japonicum (Sieb. et Zucc.) Pax et Hoffm. + Sapindus mukorossi Gaertn. + Elaeocarpus decipiens Hemsl.-Buddleja davidii Franch. + Forsythia suspensa + Hibiscus mutabilis Linn.-LotuscorniculatusL + Viola yedoensis Makino + Spiraea salicifolia L. . Pterocarya stenoptera C. DC + Sapium sebiferum (L.) Roxb. + Gleditsia sinensis Lam. + Eriobotrya japonica (Thunb.) Lindl.-Forsythia suspensa + Gardenia jasminoides Ellis + Lonicera japonica Thunb.-Dichondra repens Forst. + Cynodon dactylon (L.) Pers. + Miscanthus sinensis Andress 'Zebrinus'_Canna indica L. + Acorus calamus L. + Sagittaria sagittifolia L. + Thalia dealbata Fraser, Pterocarya stenoptera C. DC. + Cinnamomum camphora (L.) Presl. + Castanopsis sclerophylla (Lindl.) Schott.-Ternstroemia gymnanthera (Wight et Arn.) Beddome + Gardenia jasminoides var. radicans Makino. + Buddleja davidii Franch.-Dichondra repens Forst. + Viola tricolor L.

(4)pinus elliottii + Celtis sinensis Pers. + Sapindus mukorossi Gaertn. + Salix rosthornii Seemen + Sapium japonicum (Sieb. et Zucc.) Pax et Hoffm.-Hibiscus mutabilis Linn. + Yucca gloriosa L. + Lonicera japonica Thunb.-Carex 'Evergold'+ Miscanthus sinensis cv. + Cynodon dactylon (L.) Pers. + Ophiopogon japonicus (Linn. f.) Ker-Gawl.-Arundo donax var. versicolor + Oenanthe javanica (Blume) DC + Lythrum salicaria L. vinus elliottii + Pterocarya stenoptera C. DC. + Salix rosthornii Seemen-Orychophragmus violaceus + Ophiopogon japonicus (Linn. f.) Ker-Gawl. + Paspalum thunbergii Kunth ex Steud.-Phragmites australias Trin. + Pontederia cordata L. + Typha orientalis Presl

(5)Alnus trabeculosa Hand.-Mazz. + Salix rosthornii Seemen + Zelkova serrata-Paspalum thunbergii Kunth ex Steud. + Cynodon dactylon (L.) Pers. + Miscanthus sinensis CV. 、 Alnus 
trabeculosa Hand.-Mazz. + Acer buergerianum Miq. + Pyrus calleryana Decne.-Yucca gloriosa L.

+ Gardenia jasminoides var. radicans Makino.—LotuscorniculatusL + Duchesnea indica (Andr.) Focke, Alnus trabeculosa Hand.-Mazz. + Cinnamomum camphora (L.) Presl.-Salix integra 'Hakuro Nishiki'+ Hibiscus syriacus Linn. + Forsythia suspensa-Ophiopogon japonicus (Linn. f.) Ker-Gawl. + Cynodon dactylon (L.) Pers. + Orychophragmus violaceus-Typha orientalis Presl + Pontederia cordata L. + Thalia dealbata Fraser + Euryale ferox + Nymphaea L. 4. Conclusion Rational allocation of plants and their communities is vital to the sustainable rain garden landscape and one of the key factors in the urban green infrastructure. Multiple plant species and complex community structures can enhance phytocenosis landscape and landscaping effect, maintaining community stability. In establishing the rain garden landscape, it is necessary to refer to the principles for plant selection and community development methods, and make the rational plant design in combination with site conditions.

\section{Acknowledgement}

Fund project: Jiangxi Provincial College Humanities and Social Sciences Research Project 2015 (YS1525)

\section{References}

[1] Hong Quan and Tang Huichao, Rain Garden Application in Multiple Site Types from American Society of Landscape Architects Award Projects [J]. Landscape Architecture, 2012

[2] Jin Yu. Garden Plant Landscape Design [M]. Liaoning Science and Technology Publishing House, 2008

[3] Kan Liyan, Chen Weiliang, et al; Analysis of Development Technology of the Rain Garden in Shanghai Chenshan Botanical Garden [J] Acta Agriculturae Jiangxi, 2012

[4] Yang Qian and Li Yonghong, Development of Phytocenosis in the Wetland Park - Taking Hangzhou Xixi Wetland Botanical Garden for Example [J]. Chinese Tradision Gardens, 2010

[5] Wang Jia, Wang Sisi, Che Wu and Li Junqi, Rain Garden Plant Selection and Design [J]. Northern Horticulture, 2012 